\title{
One foot in the grave: zooplankton drift into the Westerschelde estuary (The Netherlands)
}

\author{
Karline Soetaert, Peter M. J. Herman \\ Netherlands Institute for Ecology, Vierstraat 28, 4401 EA Yerseke, The Netherlands
}

\begin{abstract}
The net growth rate of marine zooplankton entering the Westerschelde estuary was investigated using an advective-dispersive transport model that simulates zooplankton biomass behaving conservatively in the estuary. Total biomass of marine zooplankters in the Westerschelde was much lower than what would be expected based on transport alone, indicating negative growth rates in the estuary. Including a net consumption term in the transport model allowed the estimation of total net mortality. About $3 \%$ of all marine zooplankters that enter the Westerschelde with the flood currents are retained in the estuary, where they die. On average, $5 \%$ of the total marine zooplankton biomass in the estuary died per day. Each year a net amount of about $1500 \mathrm{t}$ of zooplankton dry weight (DW) is imported from the sea to the estuary. Thus in the Westerschelde the marine zooplankton persists mainly due to continuous replenishment from the sea. Average net production/biomass rates of the major marine zooplankton species varied from $-0.02 \mathrm{~g} \mathrm{DW}(\mathrm{g} \mathrm{DW})^{-1} \mathrm{~d}^{-1}$ (Temora longicornis) to $-0.39 \mathrm{~g} \mathrm{DW}$ $(\mathrm{gDW})^{-1} \mathrm{~d}^{-1}$ (Pseudocalanus elongatus). In the estuary, the differential mortality of these species resulted in shifts in dominance within the zooplankton community relative to that in the sea. Possible causes of this zooplankton mortality are discussed.
\end{abstract}

KEY WORDS: Zooplankton Mortality - Westerschelde - Estuary

\section{INTRODUCTION}

The Westerschelde estuary (about $100 \mathrm{~km}$ long) is a turbid, well-mixed, eutrophic estuary in the southwest of The Netherlands (Heip 1988). Water masses in the most upstream part have relatively high residence times in the estuary (about 50 to $70 \mathrm{~d}$; K. Soetaert \& P. M. J. Herman unpubl.). A turbidity maximum exists in the brackish part of the estuary. Amassment of decaying organic matter in this region causes oxygen depletion in summer (Billen et al. 1988).

The temporal and spatial patterns of the zooplankton in the Westerschelde were studied by Soetaert \& Van Rijswijk (1993). There is a well-developed community in the brackish part which consists mainly of Eurytemora affinis in winter-spring and Acartia tonsa in summer. Upstream the survival of these species is hindered by the low oxygen content of the water. In the more marine part of the estuary zooplankton populations, which include species such as Euterpina acutifrons, Acartia clausi, Pseudocalanus elongatus and Temora longicornis, enter the estuary from the sea.
They are first observed in spring, have their largest population size in summer and decline and disappear from the estuary in winter. Both the marine and brackish zooplankton populations are separated by a zone where members of both species are intermingled, but where total density is low.

In the current study we examined whether the marine populations of the Westerschelde are able to maintain themselves, and whether they thrive or are deteriorating. This relates to the problem of coastal eutrophication: estuaries are known to be important sources of nutrients and organic carbon (Wollast 1976) to the sea. This paper addresses the question of the extent to which the estuary acts as a source or sink of marine zooplanktonic carbon.

\section{MATERIAL AND METHODS}

Sampling and sample treatment. For 2 yr (April 1989 to March 1991), 12 stations located along a salinity gradient were sampled monthly. Three 100 l samples 


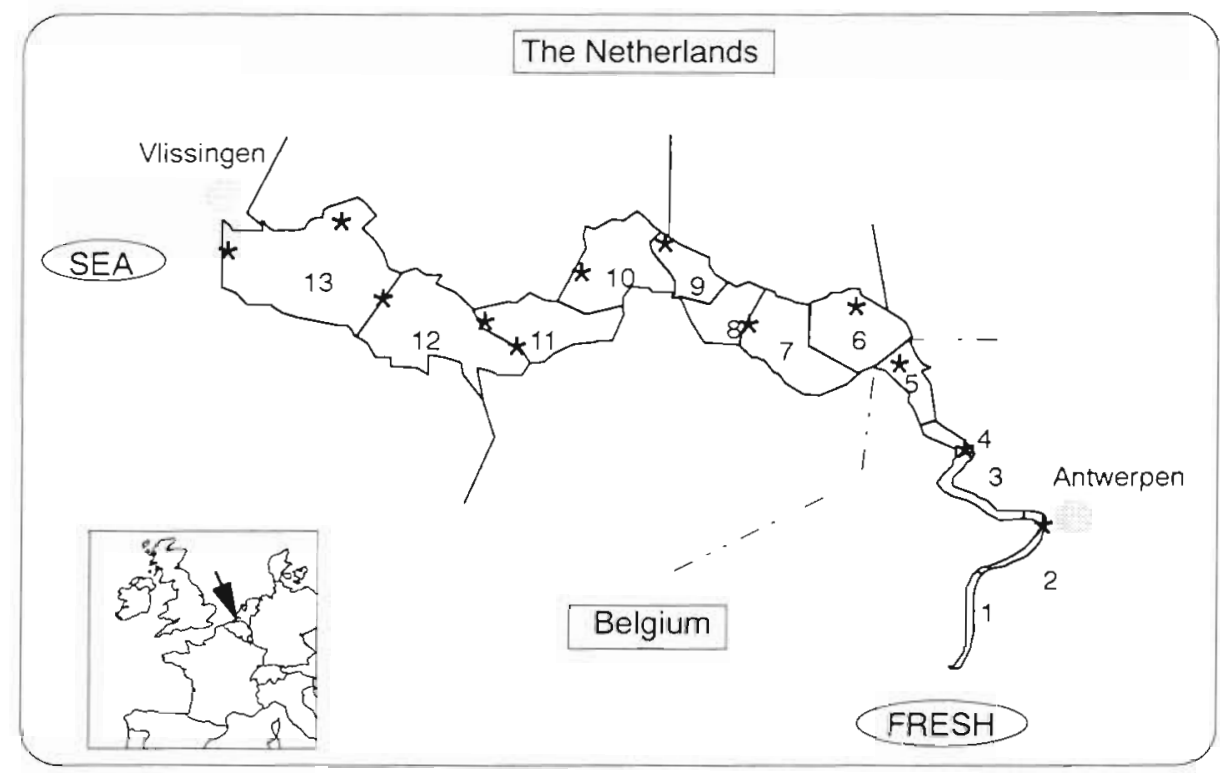

Fig. 1. The Westerschelde estuary (The Netherlands), showing the 13 compartments used in the model and the sampling locations (*). The dasheddotted line indicates the border between Belgium and The Netherlands

were collected with a pump from different depths ( $2.5 \mathrm{~m}$ below the surface, $2.5 \mathrm{~m}$ above the bottom, middepth) and poured over a $55 \mu \mathrm{m}$ mesh. For a more thorough description of sampling methods and sample processing, refer to Soetaert \& Van Rijswijk (1993). The station locations are shown in Fig. 1. Dry weights of copepods were estimated by means of lengthweight regressions, using formulae obtained from the literature (Zurlini et al. 1978, Klein Breteler et al. 1982, Kiørboe et al. 1985). Non-copepod dry weights were obtained from Castel \& Courties (1982). For a list of species belonging to the marine community in the Westerschelde, refer to Soetaert \& Van Rijswijk (1993).

Chlorophyll was measured from water samples taken simultaneously with the zooplankton samples, using reversed phase HPLC (Gieskes et al. 1988).

The dry weights of total marine zooplankton (excluding benthic larvae, protozoans and rotifers) and of the most important zooplankton species were used in a model of the Westerschelde that simulates advective and dispersive transport. The pelagic environment in this model is subdivided into 13 comparments (Fig. 1).

All zooplankton samples were first transposed to their position at mid-tide using the formula:

$$
X_{\mathrm{t}}=X_{\mathrm{m}}+\frac{\text { tidal excursion }}{2} \cos \left(\frac{t}{T} 2 \pi\right)
$$

(van Maldegem 1988), where $X_{\mathrm{t}}$ and $X_{\mathrm{m}}$ are, respectively, the transposed distance and the sampling distance from the freshwater boundary, 'tidal excursion' is the average distance a water mass travels during a tidal cycle (13 km according to van Maldegem 1988), and $t / T$ is the time of sampling relative to high water [within $(-0.5,+0.5)$ where -0.5 denotes ebb phase before current high water, +0.5 is ebb phase after current high water]. The transposed samples were then assigned to one of the model compartments (Fig. 1). In practice they occupied model compartments 2 to 13 or were transposed into the sea.

As model input, a synthetic year was created by taking the monthly average (e.g May 1989 and May 1990 values averaged to yield a synthetic May value) of samples in any compartment as representative for this compartment or the sea.

Estimating net export and net growth of the marine zooplankton. The concentration of marine zooplankton (C) in the Westerschelde estuary changes temporally due to transport (advection and dispersion) and due to in situ production or mortality. Thus:

$$
\frac{\mathrm{d} C}{\mathrm{~d} t}=\left.\frac{\mathrm{d} C}{\mathrm{~d} t}\right|_{\text {net transport }}+\left.\frac{\mathrm{d} C}{\mathrm{~d} t}\right|_{\text {net production }}
$$

Viewed over 1 yr, biomass change of marine zooplankton is zero as there is no gradual buildup or loss of zooplankton biomass in the estuary. Thus:

$$
\int_{0}^{365} \frac{\mathrm{d} C}{\mathrm{~d} t} \mathrm{~d} t=C_{365}-C_{0}=0
$$

from which it follows:

$$
\left.\int_{0}^{365} \frac{\mathrm{d} C}{\mathrm{~d} t}\right|_{\text {net transport }} \mathrm{d} t=-\left.\int_{0}^{365} \frac{\mathrm{d} C}{\mathrm{~d} t}\right|_{\text {net production }} \mathrm{d} t
$$

In other words: net losses to (or imports from) the sea integrated over the course of 1 yr must have been produced (or died) in the estuary itself.

The marine part of the Westerschelde (model compartments 9 to 13 in Fig. 1) is vertically and laterally well mixed; in the brackish part (model compartments 
3 to 8 ), small vertical gradients exist (Peters \& Sterling 1976). As zooplankters do not - in contrast to silt particles - sediment to the bottom, their transport behaviour can be modelled as if they were a dissolved substance. Dissolved transport in estuaries can be represented by the tide-averaged differential equation:

$$
\left.\frac{\partial C}{\partial t}\right|_{\text {net transport }}=-\frac{1}{A} \frac{\partial}{\partial x}(Q C)+\frac{1}{A} \frac{\partial}{\partial x}\left(E A \frac{\partial C}{\partial x}\right)
$$

(O'Kane 1980, Thomann \& Mueller 1987). Mass transport is a function of the freshwater flow (advective transport, first term) and a transport caused by heterogeneities introduced by the tides (dispersive transport, second term); here, $A$ is the cross-sectional surface area, $Q$ is the advective flow, $x$ denotes space and $E$ is the dispersion coefficient.

This differential equation is replaced by a finite difference approximation which is solved numerically by computer (K. Soetaert \& P. M. J. Herman unpubl.). Thus the change in concentrations $\left(C_{i}\right)$ in the centre of the 13 modelled compartments (Fig. 1) are described as:

$\left.\frac{\mathrm{d} C_{1}}{\mathrm{~d} t}\right|_{\text {net transport }}=$

$\frac{1}{V_{i}}\left[Q_{i-1,1} C_{i-1}-Q_{i, i+1} C_{i}+E_{i, j+1}^{\prime}\left(C_{1+1}-C_{i}\right)-E_{i-1, i}^{i}\left(C_{1}-C_{i-1}\right)\right]$

(Thomann \& Mueller 1987, K. Soetaert \& P. M. J. Herman unpubl.) where $E_{l, i+1}^{\prime}=E_{l, 1+1} \cdot A_{i, i+1} / \Delta x$, the 'bulk' dispersion coefficient $\left(\mathrm{m}^{3} \mathrm{~d}^{-1}\right) ; Q_{i, i+1}$ is the advective flow $\left(\mathrm{m}^{3} \mathrm{~d}^{-1}\right)$ between compartments $i$ and $i+1 ; A_{i, i+1}$ is the flow interface between compartments $\left(\mathrm{m}^{2}\right) ; \Delta x$ is the dispersion length ( $\mathrm{m})$; and $V_{1}$ is the volume $\left(\mathrm{m}^{3}\right)$ of compartment $i$. The values of the (constant) dispersion coefficients ( $E$ ') were calibrated based on a conservative substance (chlorinity, K. Soetaert \& P. M. J. Herman unpubl.). Compartment volumes were obtained from the SAWES database (SAWES 1991). Monthly values of advective flows were available for the period 1982 to 1988 (SAWES 1991). For the current study we used flow data of the period 1984 to 1985, but advective flows were reasonably invariant over the years, justifying the use of advective flows from a different year (1984 to 1985) with respect to the observed zooplankton data set (average of 1989 to 1991).

The yearly net export of zooplankton biomass to the sea, in $g$ dry weight (DW) $\mathrm{yr}^{-1}$, can be estimated based on Eq. (4) as:

$$
\int_{0}^{365}\left[Q_{13, \text { sea }} C_{13}+E_{13 \text { sea }}^{\prime}\left(C_{\text {sea }}-C_{13}\right)\right] \mathrm{d} t
$$

where $C_{13}$ and $C_{\text {sea }}$ are the concentrations of zooplankton in the last modelled compartment and the sea, respectively.

As marine zooplankton is not exchanged with the freshwater boundary, the yearly net export to the sea equals the sum of all yearly net transport terms in the compartments. Due to Eq. (2) this amounts to the net yearly production in the estuary.

Net production of zooplankton biomass can be represented as a linear function of the prevailing biomass:

$$
\left.\frac{\mathrm{d} C}{\mathrm{~d} t}\right|_{\text {net production }}=r C
$$

where $r$ is the daily net growth rate $\left[g D W(g D W)^{-1} d^{-1}\right]$.

The model was implemented in the simulation environment SENECA (de Hoop et al. 1993). This modelling package takes care of most routines common to modelling exercises (calibration, sensitivity analysis, numerical integration) and provides easy input-output management.

\section{RESULTS}

Temporal and spatial patterns of marine zooplankton biomass and chlorophyll

Chlorophyll in the Westerschelde attains very high values in the most upstream part of the estuary (more than $200 \mathrm{mg} \mathrm{m}^{-3}$; Fig. 2). In the brackish and marine part, values are more modest (less than $20 \mathrm{mg} \mathrm{m}^{-3}$ ). All along the estuary, 2 chlorophyll peaks are observed, one in spring and one in summer.

Total concentration ( $\mathrm{g} \mathrm{DW} \mathrm{m}^{-3}$ ) of marine zooplankton as a function of time and space is represented in Fig. 3. Marine zooplankton enter the estuary in early spring, their distributional range is largest in summer, and in winter they have nearly disappeared from the

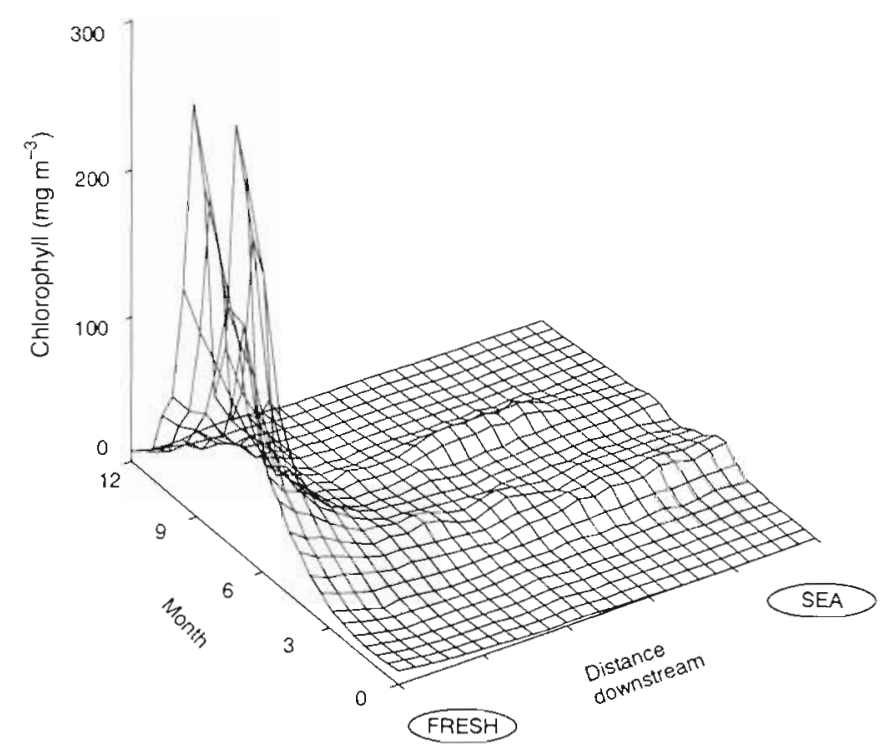

Fig. 2. Chlorophyll concentration in the Westerschelde estuary along the spatial and temporal axis 


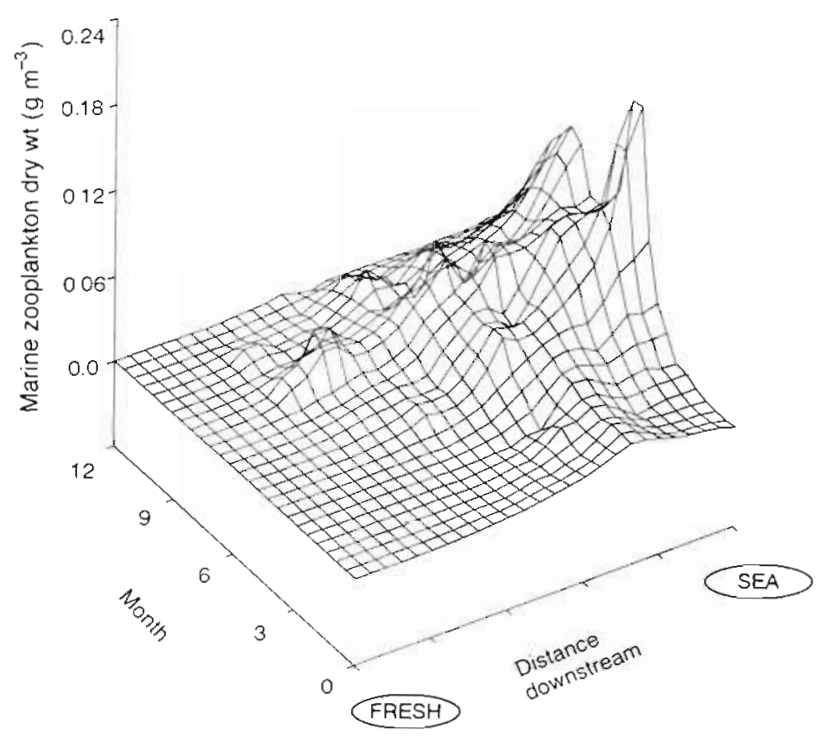

Fig. 3. Marine zooplankton dry weight in the Westerschelde estuary along the spatial and temporal axis

estuary. At nearly all times the zooplankton biomass is greatest in the sea and declines more or less steadily up the estuary. Average marine zooplankton concentration in the sea was $0.076 \mathrm{~g} \mathrm{DW} \mathrm{m}^{-3}$ and in the estuary $0.03 \mathrm{~g} \mathrm{DW} \mathrm{m}^{-3}$.

Two distinct zooplankton peaks are observed in the most marine part of the estuary, one in late spring and one in summer. Both peaks lag somewhat behind the chlorophyll peaks (Fig. 4). This bimodal zooplankton pattern fades further upstream (Fig. 3).

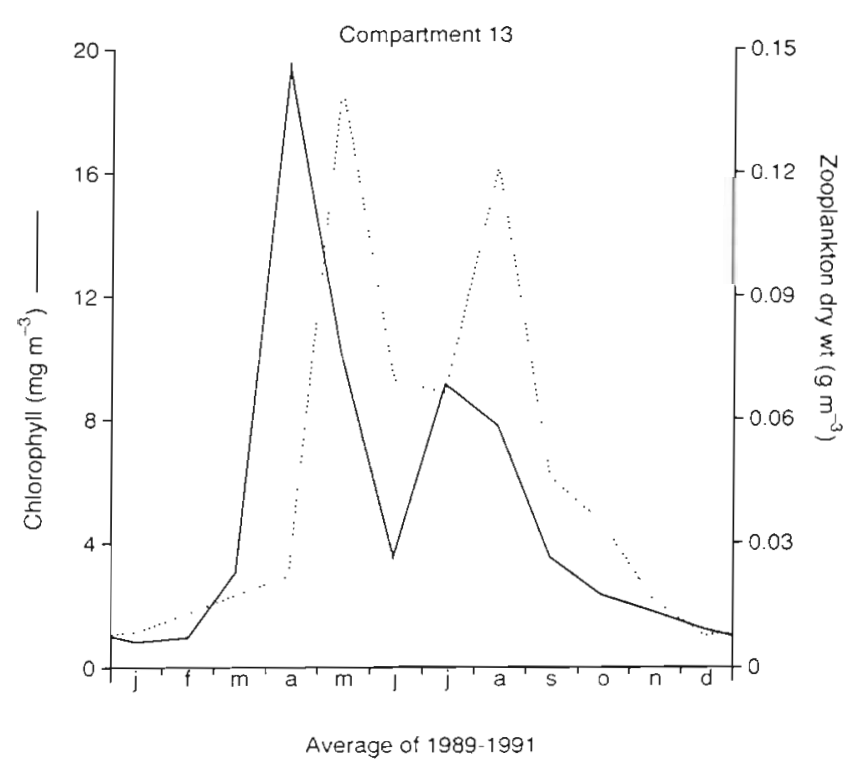

Fig. 4. Chlorophyll concentration and zooplankton dry weight in model compartment 13
For a more detailed description of temporal and spatial patterns of all zooplankton species in the Westerschelde estuary, refer to Soetaert \& Van Rijswijk (1993). An elaborate analysis of primary productivity in the estuary can be found in van Spaendonk et al. (1993).

\section{Modelling 'conservative' zooplankton biomass}

Net production or consumption of any constituent in an estuary can be assessed by comparing observed concentrations with the concentrations that occur under conditions of conservative behaviour (i.e. with zero net production). This is common practice in the study of nutrient consumption or production patterns in estuaries (e.g. Helder et al. 1983).

Using the zooplankton concentrations at the seaward boundary (average of years 1989 to 1991) and observed advective flows (1984 to 1986), we simulated the 'conservative' concentrations of total zooplankton in the various model compartments using the advective-dispersive transport equation (Eq. 4). Results are given in Fig. 5 (dotted line). These conservative concentrations represent the state in which there is no net growth; only flushing to the sea and tidal mixing are modelled. In all model compartments there was a deficit in observed zooplankton biomass with respect to the conservative concentration. This indicates that zooplankton mortality exceeds zooplankton production in the estuary and there is net decay. Average conservative biomass in the estuary is $0.06 \mathrm{gDW} \mathrm{m}^{-3}$, while observed biomass is only $0.03 \mathrm{~g} \mathrm{DW} \mathrm{m}^{-3}$.

The bimodal nature of modelled biomass, which is pronounced in the most seaward compartments, gradually diminishes upstream.

\section{Estimating net import/export of total zooplankton biomass}

Next a simulation was run with a constant net production term included, one for each modelled compartment (Eqs. 1, 4 \& 6)

Calibrating on the net production terms $(r)$ resulted in a reasonable fit for all compartments (Fig. 5, solid line). The values of the terms $r$, and the total amount of zooplankton dry weight decaying in the different model compartments are given in Table 1 . The largest amount of zooplankton $(97 \%)$ decays in the most downstream (marine) compartments $(9$ to 13) which comprise the largest volume of the Westerschelde. Only a small fraction of the zooplankton reaches the brackish region. In compartments 5 and 6 , 'best' daily loss rates were less than $1 \% \mathrm{~d}^{-1}$. 

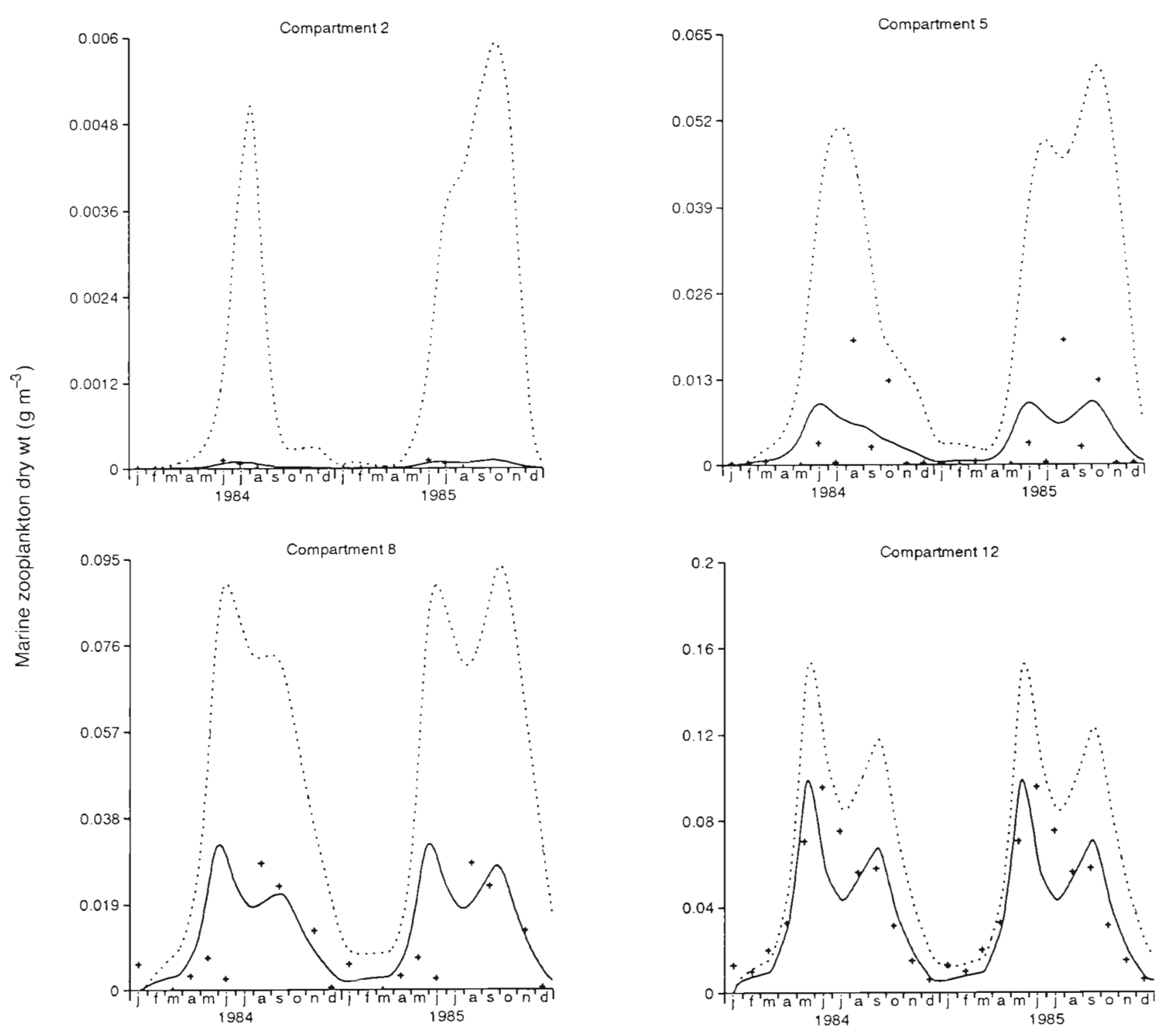

Fig. 5. Conservative zooplankton dry weight $(\cdots \cdots)$, modelled biomass $(-)$ and observed zooplankton dry weight $(+)$ in model compartments $2,5,8$ and 12

The mean net production rate of total zooplankton in the Westerschelde according to the model was $-0.05 \mathrm{~g} \mathrm{DW}(\mathrm{gDW})^{-1} \mathrm{~d}^{-1}$, i.e. on average a net loss of $5 \%$ of zooplankton biomass occurred in the Westerschelde per day.

Using Eq. (5) the yearly net export (import) to the sea was estimated. We obtained a net of $1530 \mathrm{t}$ dry weight of zooplankton that is imported from the sea each year, i.e. about $2.2 \mathrm{t}$ of dry weight per tidal period.

As the average volume of water entering the estuary each flood is about $1030 \times 10^{6} \mathrm{~m}^{3}$ (van Maldegem 1988) and the mean zooplankton dry weight in the sea is $0.076 \mathrm{~g} \mathrm{DW} \mathrm{m}^{-3}$, on average $1030 \times 0.076=78 \mathrm{t}$ of zoo- plankton dry weight enter the estuary during flood while about $2.2 \mathrm{t}$ of dry weight are retained in the estuary per flood period. Thus, about $3 \%$ of total zooplankton dry weight entering at flood is lost to the estuary per tidal cycle.

\section{Estimating yearly averaged net loss rates of the most important marine species in the estuary}

Using observed zooplankton biomass at the seaward boundary and observed biomass from the last model compartment (13), we estimated the yearly integrated 
Table 1. Best net production terms $r$, for the 13 model compartments in the Westerschelde estuary

\begin{tabular}{|ccc|}
\hline Compartment & $\begin{array}{c}r_{2} \\
\left(\mathrm{~d}^{-1}\right)\end{array}$ & $\begin{array}{c}\text { Total dry weight decaying } \\
\text { (t DW yr-1) }\end{array}$ \\
\hline 1 & -0.09 & 0 \\
2 & -0.1 & 0 \\
3 & -0.6 & 6 \\
4 & -0.6 & 9 \\
5 & -0.001 & 0 \\
6 & -0.001 & 0 \\
7 & -0.03 & 9 \\
8 & -0.03 & 16 \\
9 & -0.05 & 48 \\
10 & -0.05 & 117 \\
11 & -0.05 & 138 \\
12 & -0.05 & 402 \\
13 & -0.05 & 789 \\
Total & -0.05 & 1534 \\
\hline
\end{tabular}

amount of zooplankton exported to the sea by means of Eq. (5).

Dividing this quantity by the average biomass of the species in the estuary gives yearly production/biomass $(\bar{P} / \bar{B})$ ratios of the various species in the estuary (Eq. 2; Table 2). Provided that the net production rates are constant over the year (as in the model in the previous section), these $\bar{P} / \bar{B}$ rates are equivalent to the net production rate; otherwise they can be considered as approximations. In what follows we will denote $-(\bar{P} / \bar{B})$ as the daily loss rates.

The daily loss rates varied from 0.017 (Temora longicornis) to $0.387 \mathrm{gDW}(\mathrm{gDW})^{-1} \mathrm{~d}^{-1}$ (Pseudocalanus elongatus). In general there is an agreement between importance of the species in the estuary and the daily loss rates: the higher the daily losses, the less important the species. P. elongatus, although one of the most important components in the sea, experiences very high losses in the estuary. As a consequence, the species is much less important in the estuary.

Table 2. Estimated net loss rates $(-\bar{P} / \bar{B})$, in g DW $(\mathrm{g} \mathrm{DW})^{-1} \mathrm{~d}^{-1}$. of the most important marine species in the estuary, arranged according to decreasing biomass

\begin{tabular}{|lrrr|}
\hline Species & $-\bar{P} / \bar{B}$ & \multicolumn{2}{c|}{$\begin{array}{c}\text { \% of total biomass: } \\
\text { in estuary }\end{array}$} \\
& & 23 & 21 \\
\hline Temora longicornis & 0.017 & 19 & 15 \\
Euterpina acutifrons & 0.032 & 15 & 15 \\
Acartia clausi & 0.057 & 9 & 8 \\
Centropages hamatus & 0.032 & 6 & 21 \\
Pseudocalanus elongatus & 0.387 & 2 & 4 \\
Oithona nana & 0.157 & 24 & 3 \\
Paracalanus parvus & 0.102 & 100 & 100 \\
All other species combined & 0.014 & & \\
Average zooplankter & 0.052 & \multicolumn{3}{c}{} \\
\hline
\end{tabular}

\section{Could zooplankton behaviour be responsible for the computed negative production?}

In principle, mechanisms other than mortality, and especially vertical migration behaviour, could be responsible for the observed decrease in abundance from the seaward compartments into the estuary. Kimmerer \& McKinnon (1987b) describe a powerful mechanism for retention of zooplankton in a bay: some zooplankton species have vertical migration patterns in phase with the tide. Since the current velocity near the bottom is lower than at the surface and the zooplankton are mainly at the surface when the tide comes in, they move further upstream with the incoming tide than downstream with the outgoing tide. This mechanism was only described for typical bay-dwelling species. Kimmerer \& McKinnon (1987b) stress that, unless zooplankton are able to distinguish between the incoming and outgoing tide by perceiving their immediate surroundings, an endogenous rhythm must be assumed to explain this behaviour. While it is possible that such a behaviour would develop for bay- or estuarine-resident species (the selective advantage of the feature is apparent), it is highly improbable that the reverse behaviour would develop in neritic species. The fraction of such populations that can potentially be lost to estuaries and bays is very small. Kimmerer \& McKinnon (1987b) use this reasoning to explain why no tide-induced vertical movement can be observed in the neritic species in their study. For the neritic species in the Westerschelde, we have discarded this behavioural mechanism for the same reason. Moreover, no tide-related vertical movements have been described for zooplankton species in the North Sea, which is the main habitat for the species washed into the Westerschelde (Fransz et al. 1991). The vertical movements in the North Sea are clearly diurnal. In the nearby Southern Bight, day-night vertical migration was observed for Temora longicornis and Pseudocalanus elongatus at least during the phytoplankton bloom in May (Daro 1985).

Hill (1991) has shown that net horizontal displacement can result from the interaction between penodic vertical migration and periodic components in the tidal currents, if the periods of the vertical movement and of the tidal currents are integer multiples of each other. He pointed out the importance of the S2 (solar) component in the tide, which has a period of $12.00 \mathrm{~h}$ and therefore interacts with a diurnal vertical migration. He showed that a zooplankton organism that migrates diurnally over the entire water column can be displaced by a net of about $2 \mathrm{~km} \mathrm{~d}^{-1}$ when the amplitude of the S2 current component is $0.5 \mathrm{~m} \mathrm{~s}^{-1}$.

Although Hill's (1991) study clearly shows the existence of the effect of interaction between the S2 tidal 
component and vertical migration, the cases studied are abstract and do not really mirror the conditions in a well-mixed estuary. It is highly improbable that all zooplankton individuals would deterministically be found at an infinitely narrow, well-defined depth interval. Instead, because of vertical eddy diffusivity, vertical distribution patterns are smoothed, and this should be incorporated into a realistic estimate of the magnitude of the effect mentioned.

In what follows we will calculate the directional displacement that results in a worst-case scenario, i.e. one in which net displacement is maximal. Our calculation is based on the model of Hill (1991), but instead of allowing the zooplankton to migrate deterministically, the influence of mixing processes on the vertical distribution is included.

Kimmerer \& McKinnon (1987b) show that, if the vertical distribution of zooplankton is determined by swimming behaviour on the one hand and by eddy diffusivity on the other, the fraction of animals at depth $z$ $\left(q_{2}\right.$, in $\left.\mathrm{m}^{-1}\right)$, can be described as:

$$
q_{z}=\frac{1}{D} \frac{\omega e^{\frac{\omega) z}{D}}}{\left(\mathrm{e}^{\omega}-1\right)}
$$

where $z$ is depth, $D$ is total water depth, and $\omega$ is a dimensionless swimming speed. Order-of-magnitude considerations led Kimmerer \& McKinnon to the approximate relation $\omega=100 w$, where $w$ is swimming speed in $\mathrm{m} \mathrm{s}^{-1}$. This relationship, at least approximately, also holds for the Westerschelde.

We approached diurnal vertical migration by describing the vertical swimming speed $w$ as a periodic function of time

$$
w=W_{\max } \cos \left(\frac{2 \pi t}{24}\right)
$$

where $W_{\max }$ is maximal attainable vertical swimming speed; $t$ is time in hours from midnight; and the positive sense of the depth axis is upward ( $z=0$ at the bottom).

Horizontal movement of an average zooplankton individual at time $t$, caused by the $\mathrm{S} 2$ component of the tide, can then be represented by the following modified version of Eq. (3) in Hill (1991):

$$
\bar{u}_{\mathrm{p}}(t)=\int_{0}^{D} q_{z} U_{s}\left(\frac{z}{D}\right)^{k} \cos \left(\frac{2 \pi t}{12}-\phi\right) \mathrm{d} z
$$

where $U_{\mathrm{s}}$ is the amplitude of the $\mathrm{S} 2$ current component; $\phi$ is the phase angle of this component; and $k$ is a coefficient describing the shape of the velocity profile with water depth. According to Hill (1991), the effect is maximal at a phase value of either 0 or $\pi$.

The net daily unidirectional horizontal displacement due to the interaction between vertical migration movement and the $\mathrm{S} 2$ component of the tide can then be expressed as:

$$
u_{\mathrm{p}}=\int_{0}^{24} \bar{u}_{\mathrm{p}}(t) \mathrm{d} t
$$

As it was not possible to arrive at a manageable analytical solution for this integral, it was solved numerically for a 'worst case' approach in the particular situation of the Westerschelde: $U_{\mathrm{s}}=0.5 \mathrm{~m} \mathrm{~s}^{-1}, D=10 \mathrm{~m}$, $W_{\max }=0.02 \mathrm{~m} \mathrm{~s}^{-1}, \phi=0, k=1 / 7$.

A maximum vertical swimming speed ( $\left.W_{\max }\right)$ of $2 \mathrm{~cm}$ $\mathrm{s}^{-1}$ gives a mean velocity of about $1 \mathrm{~cm} \mathrm{~s}^{-1}$, which is high for mesozooplankton but comparable to values calculated by Kimmerer \& McKinnon (1987b). The shape of the vertical distribution profile that results from the interaction of zooplankton swimming and vertical mixing is shown in Fig. 6. Biomass increases by a factor of 6 , which is comparable to values observed by Daro (1985).
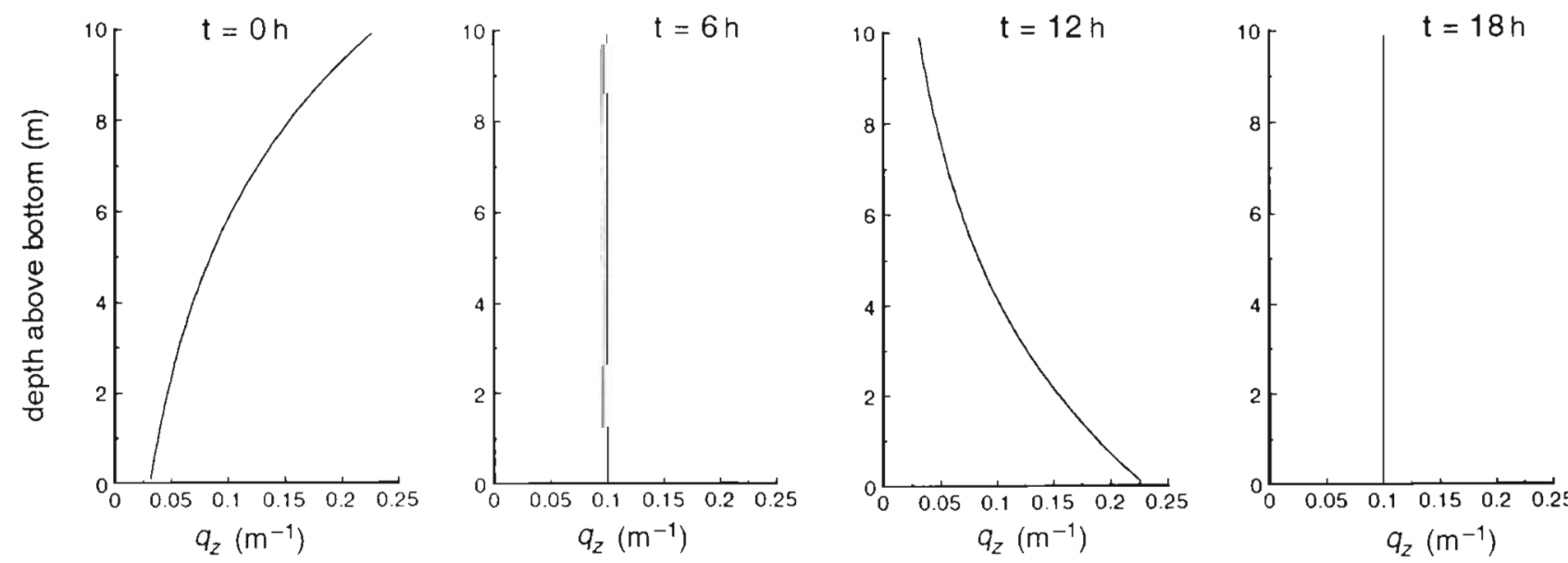

Fig. 6. Vertical distribution of a hypothetical zooplankton community that migrates diurnally at a maximum swimming speed of $2 \mathrm{~cm} \mathrm{~s}^{-1} t=0 \mathrm{~h}$ is at midnight. $q_{z}\left(\mathrm{~m}^{-1}\right)$ is the fraction of the zooplankton community residing at a given water depth 
The net displacement due to the interaction between vertical migration, vertical eddy diffusivity and the S2 component of the tidal current is then $52 \mathrm{~m} \mathrm{~d}^{-1}$. This is negligible compared with the dispersion and advective flows in the system: including this displacement as an additional term in our advective-dispersive equation yields only a $5 \%$ difference in total zooplankton imported from the sea.

It should be noted that our approach shows that, for vertical migration which is locked to the tides (as described for bay species in Kimmerer \& McKinnon $1987 \mathrm{~b})$, the horizontal displacement is on the order of $1 \mathrm{~km} \mathrm{~d}^{-1}$, which is in accordance with the conclusion of these authors that this can be an important mechanism of net transport. In the present case, however, we dismissed diurnal vertical migration as an important loss process for the estuary.

Horizontal displacement towards areas of high or low flow during different phases of the tide is another mechanism that could prevent the zooplankton from entering the estuary. However, as discussed for semidiurnal vertical migration, there is no advantage for neritic species to display this behaviour (as the chance of entering estuaries is very small). Therefore, horizontal movement is not considered a likely candidate for explaining the losses to the estuary

\section{DISCUSSION}

The Westerschelde estuary is characterized by a seasonally varying river flow (50 to $200 \mathrm{~m}^{3} \mathrm{~s}^{-1}$ ), which is relatively small compared to tidal exchange $\left(45 \times 10^{3}\right.$ $\mathrm{m}^{3} \mathrm{~s}^{-1}$ ). The tidal currents induce strong mixing which results in the exchange of marine and estuarine substances and the establishment of the typical estuarine gradient. Salinity intrudes into the estuary up to about $100 \mathrm{~km}$ upstream, and the salinity gradient moves upstream in summer when freshwater discharge is lower.

Being drifters, zooplankton organisms are particularly influenced by fluid dynamics. Along with dissolved substances, marine zooplankters will be exchanged between the estuary and the sea. Depending on their relative abundance in the two water masses and the magnitude of river discharge, this will result in either a net import into or a net export from the estuary.

In a contained water mass, zooplankton net production rates are easily determined. They are positive when the population biomass is increasing, and negative in periods of decline. In the absence of long-term trends (i.e. biomass at a given point in the year is comparable among years), net production integrated for a whole year should be zero. In systems showing a substantial exchange with foreign, adjacent waters, processes that regulate zooplankton abundance are more difficult to ascertain: one must distinguish between increase in standing stock due to in situ growth and that due to import/export processes. Numerical modelling of transport processes can provide estimates of their magnitude. In this paper we estimated the influx from the sea by means of an independently calibrated transport model (K. Soetaert \& P. M. J. Herman unpubl.). Immediately after the marine species are seen to enter the estuary, standing stock in the entire estuary is lower than expected in the case of zero net growth. It follows that marine zooplankton biomass is decaying in the Westerschelde and that zooplankton persists there mainly due to continuous supply. Mixing with seawater replenishes the stocks, and about $3 \%$ of the marine biomass that enters during flood is lost to the estuary. On a yearly basis this amounts to a net of about $1500 \mathrm{t}$ of dry weight entering and decaying in the Westerschelde.

Notwithstanding the fact that marine zooplankton biomass is introduced into the Westerschelde, a global budget shows the estuary to be an exporter of organic matter (mainly detritus) towards the sea (Wollast 1976). A substantial amount of this organic load is derived from the River Scheldt (freshwater phytoplankton, detritus) and from detrital effluents along the banks of the estuary (K. Soetaert \& P. M. J. Herman unpubl.). Salinity intolerance of the imported freshwater phytoplankton leads to high mortality in the brackish zone of the estuary (van Spaendonk et al. 1993, K. Soetaert, P. M. J. Herman \& J. Kromkamp unpubl.). Hence the Westerschelde appears to act as a graveyard of highquality organic matter (freshwater phytoplankton, marine zooplankton). Part of the detritus that is thus formed will be recycled or lost in the estuary itself, while the surplus is exported to the sea.

A comparable setup to that described here was used to estimate net zooplankton growth rates in an Australian marine bay (Kimmerer \& McKinnon 1987a). Here, too, negative net growth rates were observed for non-resident species in the Bay. They varied in magnitude from 1.5 to $3.2 \% \mathrm{~d}^{-1}$, which is comparable to the lowest net loss rates observed in the Westerschelde.

A net mortality rate in the zooplankton community of $5 \% \mathrm{~d}^{-1}$ in the Westerschelde is quite high: in the absence of external supply it will take only about $13 \mathrm{~d}$ to reduce total biomass to $50 \%$, and $44 \mathrm{~d}$ to reduce it to $10 \%$. The extremely high loss rates in the Westerschelde for Pseudocalanus elongatus $\left(0.4 \mathrm{~d}^{-1}\right)$ explain why this species, although the most important one in the adjacent sea, is insignificant in the estuary itself. Other species that exhibit less extreme loss rates increase in relative abundance in the estuary with respect to the sea (Temora longicornis, Euterpina acu- 
tifrons, Centropages hamatus). Highest losses were observed in $P$. elongatus, Oithona nana and Paracalanus parvus. According to Fransz et al. (1991), Oithona species in the North Sea originate from Atlantic waters, while the other two are what they call 'general North Sea species', i.e. present in the entire North Sea. P. elongatus is the most abundant species in the entire North Sea, and highest biomasses have often been recorded in the central part (Krause \& Martens 1990, Fransz et al. 1991 and references therein). The species T. longicornis, C. hamatus and Acartia clausi, which have moderate loss rates in the estuary, are described as typical coastal neritic constituents in Fransz et al. (1991), while E. acutifrons has a worldwide distribution in coastal, shelf and oceanic waters (d'Apolito \& Stancyk 1979). Thus it appears that species which are typical for coastal areas have the lowest mortality in the estuary, while those that are more common in offshore regions exhibit highest mortality.

Growth rates of populations are expressions of the integrated food and physical environment in which they live. One obvious factor that could be responsible for zooplankton impoverishment in the estuary is salinity. Zooplankton distributions are known to be limited by salinity but remarkably few studies have been made on salinity tolerances (Miller 1983 and references therein). Extreme conditions, rather than the average conditions that are usually perceived, could be important in determining zooplankton distribution, and even a short-term exposure to unfavourable salinities could cause death. Since almost nothing is known on the mortality of the species under study with respect to salinity, the impact of this factor on the observed pattern cannot be assessed for the Westerschelde. However, if low salinity were the major factor responsible, then mortality would be most obvious in the upstream compartments, whereas the largest losses occur near the sea.

Among the most prominent factors increasing towards the coast are turbidity and turbulence. The amount of material in suspension increases drastically coastward, while the relative content of organic matter decreases concurrently to less than $20 \%$ (Eisma \& Kalf 1987). The waters are also significantly more turbulent near the coast compared to the central regions of the North Sea (Otto et al. 1990). In the Southern Bight of the North Sea, average suspended matter concentrations in surface waters rapidly increase from about $5 \mathrm{~g}$ $\mathrm{m}^{-3}$ in the middle of the Bight to more than $100 \mathrm{~g} \mathrm{~m}^{-3}$ at the mouth of the Westerschelde (van Alphen 1990). Turbidity remains high throughout the Westerschelde estuary (Soetaert \& Van Rijswijk 1993), and on average less than $7 \%$ of total suspended matter in the marine part of the Westerschelde is of organic origin (authors' own data). As the zooplankton has to feed from the suspended mass of organics, such a substantial load of inedible particles will necessitate a large rejection or regurgitation rate and hence increase the energy demand of the feeding process whilst decreasing the assimilation efficiency. Furthermore, turbulence of the waters could interfere with the ability of the organisms to capture and handle the food material. Thus it is likely that feeding conditions for the zooplankton in the Westerschelde are so bad that they are not able to meet respiratory requirements. A deleterious effect of turbidity on copepods was demonstrated by White \& Dagg (1989) who showed that egg production of the estuarine copepod Acartia tonsa was negatively affected at high sediment concentrations. Tester \& Turner (1989) showed that the ingestion rate of a shelfwater copepod, Eucalanus pileatus, was generally lower in turbid waters compared to that in 'pure' feeding experiments. At turbidities higher than $30 \mathrm{mg} \mathrm{l}^{-1}$, the ingestion rate of this species was more depressed. Notwithistanding these studies, grazing experiments with zooplankton usually do not consider natural conditions of turbidity and turbulence, and hence the effect of these factors on the Westerschelde marine zooplankton community remains to be tested.

A closer look at the coupling of zooplankton and phytoplankton dynamics provides some insight into the ability of Westerschelde zooplankton to respond to the food environment. At the seaward boundary and due to transport effects - in the most marine part of the Westerschelde, zooplankton biomass is seen to rise shortly after phytoplankton biomass increases. More upstream, this ability to respond to phytoplankton dynamics diminishes and the coupling between zooand phytoplankton patterns disappears.

In the nearby coastal area, a deleterious effect of the unpalatable Phaeocystis on the zooplankton was postulated by Joiris et al. (1982), and this too could negatively influence Westerschelde zooplankton. However, the suitability of this flagellate as food for the zooplankton is a controversial issue and both high uptake (Weisse 1983) and strongly reduced uptake by copepods (Daro 1986, Verity \& Smayda 1989) have been documented

Whatever the causes, the decay of marine zooplankton in the Westerschelde estuary is consistent with the observed trend of decreasing importance of the mesozooplankton grazing food chain from the central to the coastal North Sea (Joiris et al. 1982) and the concomitant increasing importance of the bacterial loop. One could view the marine part of the Westerschelde estuary as an extreme coastal environment, where due to the inability of zooplankton to survive, large parts of primary production are channelled through the bacterial chain rather than the grazing food chain. In a more favourable physical setting (e.g. the central North Sea), 
then, zooplankton grazing on primary producers could be what is reducing bacterial growth.

In this paper the importance of physical structuring in the population dynamics of estuarine pelagic organisms has been clearly demonstrated. A simple but realistic transport model can be used to discriminate between physical and biological effects on population dynamics. Only a few other studies have integrated both a physical and biological approach to explain zooplankton population structure (Wroblewski 1982, Davis 1984, Kimmerer \& McKinnon 1987a, Hofmann 1988). In some other studies estuarine zooplankton dynamics were considered only as part of a global ecosystem model (Kremer \& Nixon 1978, Baretta \& Ruardij 1988).

Apart from sea-borne zooplankton constituents, the Westerschelde harbours a significant population of truly estuarine (brackish) zooplankters (Escaravage \& Soetaert 1993, Soetaert \& Van Rijswijk 1993). The global biomass distribution of Westerschelde zooplankton is bimodal, peaking in the marine and in the brackish part of the estuary. This was interpreted as representing 2 estuarine food chains, phytoplanktonbased in the marine part, detritus-based in the brackish part (Hummel et al. 1988, Hamerlynck et al. 1993). The existence of an intermediate zone of low zooplankton biomass but with high phytoplankton stocks was presented as an enigma by Hamerlynck et al. (1993). The inability of the marine zooplankton to survive in the estuary can explain why they are so scarce in this part of the Westerschelde.

Acknowledgements. For the modelling part of this study, K.S benefited from a CEC grant in the scope of the JEEP-MAST programme and from a contract from Rijkswaterstaat. Zooplankton processing was done by K.S. as part of an NFWO grant at the Free University of Brussels. Thanks to Drs van Eck and A. Schouwenaar for providing us with the data necessary for the transport submodel. This is article number 680 of the NIOO-CEMO. Drs C. Heip and M. Tackx are acknowledged for critically reading the manuscript.

\section{LITERATURE CITED}

Baretta, J. W., Ruardij, P. (1988). Tidal flat estuaries. Simulation and analysis of the Ems estuary. Springer-Verlag, Berlin

Billen, G., Lancelot, C., de Becker, E., Servais, P. (1988). Modelling microbial processes (phyto- and bacterioplankton) in the Schelde Estuary. Hydrobiol. Bull. 22: 43-55

Castel, J., Courties, C. (1982). Composition and differential distribution of zooplankton in Arcachon Bay. J. Plankton Res. 4(3): 417-433

d'Apolito, L. M., Stancyk, S. E. (1979). Population dynamics of Euterpina acutifrons (Copepoda: Harpacticoida) from North Inlet, South Carolina, with reference to dimorphic males. Mar. Biol. 54: 251-260

Daro, M. H. (1985). Feeding rythms and vertical distribution of marine copepods. Bull. mar. Sci. 37(2): 487-497
Daro, M. H. (1986). Field study of the diel, selective and efficiency feeding of the marine copepod Temora longicornis in the Southern Bight of the North Sea. Proc. Progress in Belgian Oceanographic Research. Brussels, March 1985. Royal Academy of Belgium, National Committee of Oceanology, Brussels, p. 250-263

Davis, C. S. (1984). Interaction of a copepod poplation with the mean circulation on Georges Bank. J. mar. Res. 42: $573-590$

de Hoop, B. J., Herman, P. M. J., Scholten, H., Soetaert, K. (1993). SENECA 2.0. A Simulation ENvironment for ECological Application. Netherlands Institute of Ecology, Yerseke

Eisma, D., Kalf, J. (1987). Distribution, organic content and particle size of suspended matter in the North Sea. Neth. J. Sea Res. 21: 265-285

Escaravage, V., Soetaert, K. (1993). Estimating secondary production for the brackish Westerschelde copepod population Eurytemora affinis (Poppe) combining experimental data and field observations. Cah. Biol. mar. 34: 201-214

Fransz, H. G., Colebrook, J. M., Gamble, J. C., Krause, M. (1991). The zooplankton of the North Sea. Neth. J. Sea Res. 28(1/2): 1-52

Gieskes, W. W. C., Kraay, G. W., Nontji, A., Setiapermana, D., Sutomo (1988). Monsoonal alteration of a mixed and layered structure in the phytoplankton of the euphotic zone of the Banda Sea (Indonesia), a mathematical analysis of algal pigment fingerprints. Neth. J. Sea Res. 22: 123-137

Hamerlynck, O., Mees, J., Craeymeersch, J. A., Soetaert, K., Hostens, K. Cattrijsse, A., Van Damme, P. A. (1993). The Westerschelde estuary: two food webs and a nutrient-rich desert. In: Progress in Belgian Oceanographic Research. Royal Academy of Belgium, National Committee of Oceanology, Brussels, p. 217-234

Heip, C. (1988). Biota and abiotic environment in the Westerschelde estuary. Hydrobiol. Bull. 22(1): $31-34$

Helder, W., de Vries, R. T. P., Rutgers van der Loeff, M. M. (1983). Behaviour of nitrogen nutrients and silica in the Ems-Dollard estuary. Can. J. Fish. Aquat. Sci. 40 (suppl. 1): $188-200$

Hill, A. E. (1991). A mechanism for horizontal zooplankton transport by vertical migration in tidal currents. Mar. Biol. 111: $485-492$

Hofmann, E. E. (1988). Plankton dynamics on the outer southeastern U. S. continental shelf. III. A coupled physicalbiological model. J. mar. Res. 46: 919-946

Hummel, H., Moerland, G., Bakker, C. (1988). The concomitant existence of a typical coastal and a detrital food chain in the Westerschelde estuary. Hydrobiol. Bull. 22: 35-41

Joiris, C., Billen, G., Lancelot, C., Daro, M. H., Mommaerts, J. P., Bertels, A., Bossicart, M., Nijs, J. (1982). A budget of carbon cycling in the Belgian coastal zone: relative roles of zooplankton, bacterioplankton and benthos in the utilization of primary production. Neth. J. Sea Res. 16: 260-275

Kimmerer, W. J., McKinnon, A. D. (1987a). Zooplankton in a marine bay. I. Horizontal distributions used to estimate net population growth rates. Mar. Ecol. Prog. Ser. 41: 43-52

Kimmerer, W. J., McKinnon, A. D. (1987b). Zooplankton in a marine bay. II. Vertical migration to maintain horizontal distributions. Mar. Ecol. Prog. Ser. 41: 53-60

Kiørboe, T., Møhlenberg, F., Hamburger, K. (1985). Bioenergetics of the planktonic copepod Acartia tonsa: relation between feeding, egg production and respiration and composition of specific action. Mar. Ecol. Prog. Ser. 26 $85-97$

Klein Breteler, W. C. M., Fransz, H. G., Gonzalez, S. R. (1982) Growth and development of four calanoid copepod spe- 
cies under experimental and natural conditions. Neth. J. Sea Res. 16: 195-207

Krause, M., Martens, P. (1990). Distribution patterns of mesozooplankton biomass in the North Sea. Helgoländer Meeresunters. 44: 295-327

Kremer, J. N., Nixon, S. W. (1978). A coastal marine ecosystem. Simulation and analysis. Springer Verlag, Berlin

Miller, C. B. (1983). The zooplankton of estuaries. In: Ketchum, B. H. (ed.) Estuaries and enclosed seas. Elsevier, Amsterdam, p. 103-149

O'Kane, J. P. (1980). Estuarine water-quality management. Pitman, Boston

Otto, L., Zimmerman, J. T. F., Furnes, G. K., Mork, M., Saetre, R., Becker, G. (1990). Physical oceanography of the North Sea. Neth. J. Sea Res. 26(2-4): 161-238

Peters, J. J., Sterling, A. (1976). Hydrodynamique et transports de sédiments de l'estuaire de l'Escaut. In: Nihoul, J. C. J., Wollast, R. (eds.) L'Estuaire de l'Escaut. Projet Mer. Rapport final, Vol. 10. Service du Premier Ministre, Bruxelles, p. 1-70

SAWES (1991). Waterkwaliteitsmodel Westerschelde. WLrapport T257. Waterloopkundig Laboratorium, Delft

Soetaert, K., Van Rijswijk, P. (1993). Spatial and temporal patterns of the zooplankton in the Westerschelde estuary. Mar. Ecol. Prog. Ser. 97:47-59

Tester, P. A., Turner, J. T. (1989). Zooplankton feeding ecology: Feeding rates of the copepods Acartia tonsa, Centropages velificatus and Eucalanus pileatus in relation to the suspended sediments in the plume of the Mississippi River (Northern Gulf of Mexico continental shelf). Scientia mar. 53(2-3): 231-237

Thomann, R. V., Mueller, J. A. (1987). Principles of surface water quality modelling and control. Harper \& Row, New York

This article was submitted to the editor van Alphen, J. S. L. J. (1990). A mud balance for BelgianDutch coastal waters between 1969-1986. Neth. J. Sea Res. 25(1): $19-30$

van Maldegem, D. (1988). Verzeilen van de immissiegegevens van the oppervlaktewater van het Schelde estuarium over de periode $1975 \mathrm{t} / \mathrm{m} 1986$. Internal report RWS GWAO-88. 1267. Rijkswaterstaat, Middelburg

van Spaendonk, J. C. M., Kromkamp, J. C., de Visscher, P. R. M. (1993). Primary production of phytoplankton in a turbid coastal plain estuary, the Westerschelde (The Netherlands). Neth. J. Sea Res. 31(3): 267-279

Verity, P. G., Smayda, T J. (1989). Nutritional value of Phaeocystis pouchetii (Prymnesiophyceae) and other phytoplankton for Acartia spp. (Copepoda): ingestion, egg production and growth of nauplii. Mar Biol. 100: $161-171$

Weisse, $\Upsilon$. (1983). Feeding of calanoid copepods in relation to Pheaocystis pouchetii blooms in the German Wadden Sea area off Sylt. Mar. Biol. 74: 87-94

White, J. R., Dagg, M. J. (1989). Effects of suspended sediments on egg production of the calanoid copepod Acartia tonsa. Mar. Biol. 102: 315-319

Wollast, R. (1976). Transport et accumulation de polluants dans l'estuaire de l'Escaut. In: Nihoul, J. C., Wollast, R. (eds.) L'Estuaire de l'Escaut. Projet Mer. Rapport final, Vol. 10. Service du Premier Ministre, Bruxelles, p. $191-201$

Wroblewski, J. S., (1982). Interaction of currents and vertical migration in maintaining Calanus marshallae in the Oregon upwelling zone - a simulation. Deep Sea Res. 29: $665-686$

Zurlini, G., Ferrari, I., Nassogne, A. (1978). Reproduction and growth of Euterpina acutifrons (Copepoda: Harpacticoida) under experimental conditions. Mar. Biol. 46: 59-64

Manuscript first received: August 31, 1993

Revised version accepted: November 19, 1993 